\title{
Aspects to Consider for a More Useful, Discriminative Predictive Tool for CAP Mortality in T2DM [Letter]
}

This article was published in the following Dove Press journal: Diabetes, Metabolic Syndrome and Obesity: Targets and Therapy

\section{Dan Geltser (D)}

Imperial College London, School of Medicine, London, UK
Correspondence: Dan Geltser

Email dgIII6@ic.ac.uk

\section{Dear editor}

I read with great interest the paper by Ma et al ${ }^{1}$ which explored the sensitivity and specificity of using CURB-65 and the PSI scoring systems to predict mortality in type 2 diabetes mellitus (T2DM) patients with community-acquired pneumonia (CAP). The study importantly identified the need for a more specific prediction model in T2DM cohorts. CAP accompanied with T2DM commonly presents in both primary care and the ED and as a 5th-year medical student I would like to highlight other factors which should be discussed when considering the conclusion and aid the development of a more useful, discriminative tool for the diagnosis and prognosis of CAP in T2DM.

I would like to commend the study on underlining the significant difference in mortality based on age in both the diabetic and non-diabetic cohort. This is understood to be due to weakened immune systems and worsening lung function in older patients, which is further affected by other comorbidities. However, the purpose of the paper was to compare the effectiveness of the scoring systems and studies have shown that the PSI overvalues the age variable. ${ }^{2}$ Furthermore, the study used a cohort aged $66.6 \pm 17.3$ years, which is a substantial age range. This may not be useful in identifying whether mortality prediction was solely affected by the diabetes or the difference between age groups; retrospective studies have shown that in general there is a significant increase in mortality and worse outcomes in patients $\geq 65$ with CAP and a further increase of $29.7 \%$ in patients $\geq 85$ years. ${ }^{3}$ In a longitudinal study, the paper may wish to use a cohort with a smaller variation in age.

The paper correctly highlighted that COPD and asthma are factors to be considered when looking at CAP outcomes. However, the study did not consider other respiratory pathology which could affect outcomes in pneumonia including other acute infections (eg, TB) or more chronic illnesses (eg, sarcoid or CF). Other immunodeficiency's and previous hospitalisations of CAP were not excluded, which could be confounding.

The study did not identify the specific strains of CAP the patients had or whether patients had resistance to certain antibiotics, which could all affect their mortality. Furthermore, a reason why the predictive tools may be less discriminative in the T2DM cohort is because CAP may have more atypical presentations in these patients, which was not considered. 
In conclusion, a more useful system would take into account factors such as glycaemic control, where studies have shown that hyperglycaemia significantly increases pneumonia-related mortality. ${ }^{4}$ A new predictive model for CAP in T2DM should put more weighting on risk factors associated with greater mortality in the disease such as renal disease and ischaemic heart disease. T2DM patients also have an increased risk of microvascular complications such as peripheral nephropathies and these can significantly increase the risk of bacteraemia and sepsis, which should also be taken into account when developing a new predictive scoring system for pneumonia.

\section{Disclosure}

The author reports no conflicts of interest in this communication.

\section{References}

1. Ma C, Wang N, Su Q, Yan Y, Yin F. The performance of CURB-65 and PSI for predicting in-hospital mortality of community-acquired pneumonia in patients with type 2 diabetes compared with the non-diabetic population. Diabetes Metab Syndr Obes. 2021;14:1359-1366. doi:10.2147/DMSO.S303124

2. Chen J, Chang S, Liu JJ, et al. Comparison of clinical characteristics and performance of pneumonia severity score and CURB-65 among younger adults, elderly and very old subjects. Thorax. 2010;65 (11):971-977. doi:10.1136/thx.2009.129627

3. Zhang ZX, Yong Y, Tan WC, Shen L, Ng HS, Fong KY. Prognostic factors for mortality due to pneumonia among adults from different age groups in Singapore and mortality predictions based on PSI and CURB-65. Singapore Med J. 2018;59(4):190-198. doi:10.11622/ smedj.2017079

4. Kornum JB, Thomsen RW, Riis A, Lervang HH, Schønheyder HC, Sørensen HT. Type 2 diabetes and pneumonia outcomes: a population-based cohort study. Diabetes Care. 2007;30 (9):2251-2257. doi:10.2337/dc06-2417

Dove Medical Press encourages responsible, free and frank academic debate. The content of the Diabetes, Metabolic Syndrome and Obesity: Targets and Therapy 'letters to the editor' section does not necessarily represent the views of Dove Medical Press, its officers, agents, employees, related entities or the Diabetes, Metabolic Syndrome and Obesity: Targets and Therapy editors. While all reasonable steps have been taken to confirm the content of each letter, Dove Medical Press accepts no liability in respect of the content of any letter, nor is it responsible for the content and accuracy of any letter to the editor.

Diabetes, Metabolic Syndrome and Obesity: Targets and Therapy

\section{Publish your work in this journal}

Diabetes, Metabolic Syndrome and Obesity: Targets and Therapy is an international, peer-reviewed open-access journal committed to the rapid publication of the latest laboratory and clinical findings in the fields of diabetes, metabolic syndrome and obesity research. Original research, review, case reports, hypothesis formation, expert opinion and commentaries are all considered for publication. The manuscript management system is completely online and includes a very quick and fair peer-review system, which is all easy to use. Visit http://www.dovepress.com/testimonials.php to read real quotes from published authors.

Submit your manuscript here: https://www.dovepress.com/diabetes-metabolic-syndrome-and-obesity-targets-and-therapy-journal 